\title{
Kehidupan Sosial-Ekonomi Masyarakat Samin Kabupaten Bojonegoro dan Potensinya Sebagai Sumber Belajar Sejarah Lokal
}

\author{
Marga Bayu Kurniawan ${ }^{1}$, Novi Triana Habsari², Muhammad Hanif ${ }^{3}$ \\ 1,2Program Studi Pendidikan Sejarah, FKIP, Universitas PGRI Madiun \\ ${ }^{3}$ Program Studi Magister Pendidikan IPS, Pascasarjana, Universitas PGRI Madiun \\ Email: novitrianahabsari@unipma.ac.id
}

\begin{abstract}
Abstrak: Kebudayaan masyarakat Samin tidak mengajarkan anak cucu mereka untuk bekerja di luar dari desa, karena takut melupakan kultur budayanya. Suasana kehidupan ini berpengaruh terhadap kehidupan sosial ekonomi masyarakat Samin. Penelitian bertujuan menungkap kehidupan sosial ekonomi masyarakat Samin Kabupaten Bojonegoro. Metode penelitian menggunakan kualitatif deskriptif. Pengumpulan data dengan wawancara, observasi dan dokumentasi dengan analisis interaktif. Hasil penelitian menunjukkan interaksi sosial masyarakat di Desa Meduri masih terjaga seperti gotong royong dan kekeluargaan hingga saat ini. Akses jalan masih berbatu dan tempat tinggal di dalam hutan semakin terisolasi. Sehingga terpengaruh pada ekonomi yang berdampak pada anak-anak yang belum menempuh pendidikan. Kehidupan ekonomi pengrajin dan pencari bonggkahan bonggol jati berada di lapiasan bawah karena upah yang diterima tidak terlalu besar dan menentu. Kehidupan sosial ekonomi masyarakat Samin ini berpotensi sebagai sumber pembelajaran sejarah lokal. Berdasarkan kurikulum 2013 edisi revisi pada kelas X mata pelajaran sejarah, terdapat KD 3.6 Menganalisis perkembangan kehidupan masyarakat, pemerintahan, dan budaya pada masa kerajaan-kerajaan Hindu dan Buddha di Indonesia serta menunjukkan contoh bukti-bukti yang masih berlaku pada kehidupan masyarakat Indonesia masa kini yang sesuai dengan penelitian ini. Dengan mempelajari kehidupan sosial ekonomi masayarakat Samin secara langsung, mahasiswa dapat menambah wawasan kebangsaan tentang tradisi masa lampau yang tetap dilestarikan sebagai pemersatu bangsa.
\end{abstract}

\section{Kata Kunci: Sosial, Ekonomi, Samin, Sejarah}

Abstract: The Samin culture does not teach their children and grandchildren to work outside the village, for fear of forgetting their cultural culture. The atmosphere of this life affects the social economy of the Samin community. The research aims to reveal the social and economic life of the people of Samin, Bojonegoro Regency. The research method uses descriptive qualitative. Data collection by interview, observation and documentation with interactive analysis. The results of the study showed that social interactions in the village of Meduri are still maintained, such as mutual cooperation and kinship to this day. Access roads are still rocky and dwellings in the forest are increasingly isolated. So it is affected by the economy which affects children who have not yet studied. The economic life of teak weavers and artisans are in the lower lapiasan because the wages received are not too large and uncertain. The social and economic life of the Samin community has the potential to be a source of learning local history. Based on the revised edition of the 2013 curriculum in class X history subjects, there is KD 3.6 Analyzing the development of community life, government, and culture during the Hindu and Buddhist kingdoms in Indonesia and shows examples of evidence that still applies to the lives of Indonesian people today who in accordance with this study. By studying the social and economic life of the Samin community firsthand, students can add to the national outlook about the traditions of the past which remain preserved as a unifying nation.

Keywords: Social, Economy, Samin, History

\section{Pendahuluan}

Indonesia memiliki wilayah yang

luas. Sebuah negara besar yang dihuni oleh penduduk dalam jumlah yang besar pula, yakni lebih dari 260 juta jiwa.

Penduduknya terdiri atas sejumlah kelompok masyarakat, tinggal menyebar di berbagai pulau yang membentang dari 
ujung barat dan ujung timur. Kelompokkelompok masyarakat tersebut memiliki latar belakang yang berbeda satu sama yang lain, dan berbedaan tersebut dapat memberikan gambaran jati diri yang khas bagi setiap kelompok masyarakat berikut karakteristiknya budaya yang mereka miliki mewarnai kehidupan berbangsa dan bernegara. Melihat kenyataan bahwa masyarakat Indonesia sangat heterogen, maka tidak mudah menciptakan kondisi yang selaras dengan tujuan pembangunan nasional.

Perubahan yang terjadi dalam mayarakat tidak terlepas dari perkembangan ilmu pengetahuan dan teknologi yang semakin luas. Hal yang demikian tersebut merupakan suatu makna perubahan dalam masyarakat, yang bergerak dari keadaan tradisional ataupun pra modern menuju masyarakat yang modern (Abdulsyani dalam Septikawati Habsari, 2014). Ada mereka yang menerima pembaharuan atau modernisasi, baik yang berasal dari program-program globalisasi yang terjadi pada saat ini.

Namun tak bisa di pungkiri pula masih tersisa sejumlah kelompok masyarakat tidak perduli hal yang berbau modern. Masyarakat yang menggambarkan kondisi tersebut adalah masyarakat Samin yang hidup dalam sebuah lingkungan adat yang dipatuhinya. Mereka hidup dalam kelompok yang memisahkan diri secara formal dari tatanan budanya pada umumnya. Pada dasarnya kehidupan masyarakat saat ini sudah mengalami perubahan secara dinamis. Hal menunjukan bahwa pola masyarakat masih menginginkan suatu bentuk kehidupan megarah lebih modern. Terbukti dengan pergeseran nilai sosial, perilaku, stratifikasi sosial, kekuasaan, wewenang dan sebagainya (Rusdianata dalam Septikawati \& Habsari, 2014). Dari sisi historis, masyarakat Samin (sedulur sikep) adalah komunitas yang berasal dari ketokohan dan pemikiran atau ajaran pemimpin masyarakat yang bernama Samin Surosendiko yang lahir pada 1859 dengan nama Raden Kohar di Desa Ploso Kedhiren Randublatung Kabupaten Blora.

Dia merupakan putera dari Raden Surowijoyo. Samin Surosendiko bernama Priyayi Raden Kohar sementara nama yang merakyat dari dia adalah Samin (Purwasito dalam Munadi, 2014). Kata Samin sendiri berarti sami-sami amin (Purwasito dalam Munadi, 2014:2). Ajaran Saminisme bermula dari sebuah kegelisahan $R$. Surowijoyo yang tidak tahan terhadap perilaku pemerintahan kolonial Belanda sebagai penjajah.

R. Surowijoyo kemudian melakukan sebuah gerakan moral sehingga merubah namanya menjadi Samin (Sami-Sami Amin atau sama rata, sejahtera dan mufakat). Sebuah pemberian nama yang bernafaskan wong cilik, serta berjuluk Samin Sepuh. Banyak orang memandang Samin dengan 
penilaain yang berbeda-beda, ada yang baik dan ada yang salah dalam mempersepsikan. Mulai anggapan bahwa gerakan masyarakat Samin sebagai simbol perlawanan terhadap kekuasaan Kolonial Belanda sampai anggapan bahwa masyarakat Samin adalah kumpulan orangorang yang tak beragama, aneh dan terbelakang. Samin oleh sebagaian besar orang lebih sering memandang dengan kacamata buram atau pandangan negatif. Tidak mau membayar pajak, suka membangkang dan menentang. Saminisme sebenarnya merupakan sebuah paham dan sejarah perlawanan terhadap kekuasaan Kolonial Belanda yang telah diubah menjadi deskripsi kebudayaan.

Perlawanan terhadap Belanda dengan cara inilah yang kadang dipakai oleh masyarakat Samin yaitu dengan menyebut mereka dengan menyebut dirinya Sedulur Sikep. Hal ini menepis anggapan buruk sebutan Samin yang mempunyai arti buruk di kalangan orang yang belum mengenal arti Sedulur Sikep. Hafiah istilah sedulur atau wong sikep bermakna saudara atau orang bertabiat baik jujur. Ungkapan itu mengacu pada paguyupan panganut ajaran Samin (Titi Mumfangati dalam Munadi, 2014).

Komunitas Samin memiliki ciri-ciri khas yang menjadi identitas mereka dalam penampilan sehari-hari yang berbeda dengan masyarakaat disekitarnya. Identitas tersebut menunjukan dan penampilan mereka sesuai dengan ajaran Saminisme yang mereka pertahankan dari waktu ke waktu terutama generasi tua. Mereka merasakan kebenaran dan keyakinan yang kuat terhadap ajaran Samin Surosendiko sebagai pandangan hidup berguna sikap dan perbuatan orang-orang Samin selalu diikuti bukti-bukti nyata dan konsekuen sesuai ajaran yang di teriamanya. Perubahan tersebut sebenarnya belum terlihat pada masyarakat Samin secara keseluruhan.

Hal ini disebabkan pemikiran dari masyarakat Samin masih cenderung sikap hidup yang masih tradisional. Sikap seperti ini disebabkan pemikiran masyarakat Samin yang masih tertutup dan belum ada interaksi dengan masyarakat luar. Keadaan pola ajar yang dilaksanakan sesuai dengan prinsip ajaran Samin Surosendiko yang yang dijadikan pedoman bersikap dan bertingkah laku yang baik dan jujur khususnya masyarakat Samin (Mumfangati dalam Septikawati dan Habsari, 2014).

Ajaran hidup yang unik dari masyarakat Samin yang ditanamkan bagi generasi penerusnya merupakan doktrin dari orang tuanya (terutama ayah) sejak lahir dengan bekal teladan baik (uswatun khasanah) untuk keluargannya dan masyarakat. Adapun ajaran hidup masyarakat Samin Desa Meduri Kecamatan Margomulyo Kabupaten Bojonegoro meliputi: kudu weruh te'e dhewe, lugu, lan mligi (Darmanto Jatman dalam munadi, 
2014). Kudu weruh te'e dhewe, yaitu harus memahami kepemilikanya sendiri maksudnya untuk membedakan miliknya pribadi dengan milik oang lain kepemilikannya pribadi dan jika menggunakan (meminjam) milik orang lain harus seizinnya. Lugu, dapat diberi makna kosisten maksudnya jika dapat perjanjian hanya dua pilihan jawaban antara iya dan tidak, hal ini dengan harapan tidak menimbulkan kekecewaan pihak lain jika jawaban dengan realitas kontradiktif. Mligi dapat diberi tafsiran kosekuen atau bertanggung jawab dengan prinsip hidup yang telah peganginganya sekaligus meninggalkan pantangan hidup.

Tidak diperbolehkan berpakaian secara umum, misalnya celana panjang dan berpeci, hal ini lebih bertendensi pada primordialisme kelompok, mereka memiliki pakaian khas berupa suwal, celana yang panjangnya di bawah lutut, udeng ikat kepala, dan bebhet atau sarung. Warna khas pakaiannya adalah warna hitam dan jika bertani menggunakan pakaian seperti bercaping, berkaos, atau berpakaian seperti lazimnya masyarakat nonmuslim ketika berladang.

Selanjutnya adalah menukan
barang petil-jumput, prinsip yang di
pengangi dengan adanya larangan
menemukan barang dan pantangan
akhirnya adalah mencuri bedhok-colong,
apa lagi mencuri merupakan pantangan.
Sehingga watak hidup ideal masyarakat

Jawa. Kehidupan masyarakat silih berganti dengan adannya perubahan dari sektor perubahan sosial dan ekonomi yang merubah kesejahtraan untuk memenuhi kehidupan sehari-hari. Banyak pekerjaan yang sudah disediakan dan menjadi pilihan untuk memperbaiki taraf hidup yang lebih baik. Kebudayaan Samin tidak mengajarkan anak cucu mereka untuk bekerja di luar dari desa mereka dikarenakan mereka takut melupakan kultur budaya yang telah dia tanamkan dari kecil yang sudah diberikan oleh orang tuanya.

Keunikan yang terdapat pada masyarakat Samin sangat menarik untuk dijadikan sumber belajar terutama sejarah lokal agar wawasan mahasiswa tentang multikultural, pluralisme bahkan kebangsaan semakin bertambah. Ilmu sejarah berusaha mengungkap masa lampau manusia berdasarkan sumbersumber sejarah dan dibantu dengan ilmu bantu sejarah serta ilmu-ilmu sosial. Dengan demikian diharapkan fakta/data masa lampau itu benar adanya, sesuai dengan struktur dalam ilmu sosial khususnya sejarah tujuannya adalah kebenaran.

Sedangkan sumber pembelajaran adalah sarana pembelajaran dan pengajaran yang sangat penting. Sudah menjadi keharusan bagi seorang guru untuk mengeksplorasi berbagai macam sumber untuk mendapatkan alat bantu yang tepat untuk mengajar dan melengkapi 
apa yang sudah disediakan di dalam buku cetak, untuk membangkitkan minat peserta didik. Adapun jenis-jenis sumber pembelajaran yang bisa digunakan oleh seorang guru sebagai berikut; (1) silabus; (2) panduan kurikulum; (3) buku panduan guru yang berisi bab-bab dan sumbersumber pembelajaran; (4) buku cetak utnuk pegangan guru; (5) buku-buku tambahan untuk bidang studi yang sedang dipelajari; dan yang terakhir (6) sumbersumber referensi umum seperti yang tercantum pada nomor 5 (Kochhar, 2008: 160-161).

\section{Metode}

Pendekatan kualitatif merupakan suatu metode penelitian yang di tunjukan untuk mendreskipsikan dan menganalisa fenomena, peristiwa, aktivitas sosial, sikap, kepercayaan, persepsi, pikiran orang baik secara individual ataupun kelompok (Sukmadinata, 2011). Jenis penelitian yang dipilih penelitian kualitatif deskriptif. Deskriptif dalam catatan data ini meliputi potret subyek, rekrontruksi, dialog, deskripsi keadaan fisik, struktur tentang tempat dan peninggalan yang ada disekitarnya.

Demikian juga catatan tentang berbagai peristiwa khusus (termasuk siapa yang terlibat dengan cara bagaimana, gerak-geriknya, dan juga tingkah laku atau sikap penelitiannya) (Sutopo: 2002). Dalam penelitian kualitatif tentunya juga membutuhkan sumber data agar hasil dari penelitian dapat valid. Sumber data yang digunakan yakni sumber data primer dan sumber data sekunder. Sumber primer adalah sumber data yang langsung memberikan data kepada pengumpul data. Sumber primer diperoleh dari sumber pertama melalui prosedur dan teknik pengambilan data yang berupa observasi, wawancara maupun penggunaan instrumen yang khusus dirancang sesuai dengan tujuan. Sumber data sekunder adalah data yang diperoleh dari sumber tidak langsung. Data ini dapat ditemukan dengan cepat. Data sekunder umumnya berupa bukti, catatan atau laporan historis yang telah tersusun dalam arsip.

Sumber data sekunder ini dapat membantu peneliti untuk membantu mendapatkan sebuah bukti bahan yang diteliti untuk mendapatkan sebuah bukti bahan yang ingin diteliti. Pengumpulan data dilakukan dengan wawancara, observasi, dan dokumentasi bertujuan untuk mengamati kehidupan sosial dan ekonomi Sedulur Sikep di Desa Meduri. Penelitian dilaksanakan selama 4 bulan. Dipilihnya waktu 4 bulan dikarenakan peneliti menganggap bahwa waktu tersebut sudah cukup untuk mengumpulkan data yang dibutuhkan.

Untuk mendapatkan data yang valid, setelah data terkumpul dilakukan trianggulasi sumber. Sumber-sumber yang didapatkan dibandingkan dengan sumber 
yang lain. Tahap analisis data dilakukan dalam 3 tahap, yang pertama adalah tahap reduksi data. Data yang diperoleh dari penelitian tentunya sangat banyak. Untuk itu perlu dilakukan reduksi data. Menurut Miles dan Huberman (1994). Dalam tahap reduksi data, peneliti melakukan proses seleksi, pemfokusan, penyerderhanaan dan abstraksi data dari sumber penelitian. Reduksi data merupakan bagian dari proses analisis yang mempertegas, memperpendek, membuat fokus, membuat hal-hal yang tidak penting dan mengatur data sedemikian rupa sehingga simpulan peneliti dapat dilakukan.

Peneliti melakukan tahap reduksi data dengan membaca secara cermat objek penelitian dan kemudian dibagi ke dalam kategori sesuai kajian yang peneliti amati. Dalam tahap ini data yang didapat akan dipilah-pilah dalam kategori tertentu, pemilihan data dilakukan agar data yang akan diolah sesuai dengan yang diinginkan peneliti. Tahap kedua adalah tahap penyajian data yakni dengan meringkas kumpulan dari informasi yang memperbolehkan penarikan kesimpulan dan tindakan. Setelah data direduksi, maka langkah selanjutnya adalah penyajian data. Dalam Miles dan Huberman (1994).

Sajian data merupakan suatu rakitan organisasi informasi, deskripsi dalam bentuk narasi yang memungkinkan simpulan penelitian dapat dilakukan. Sajian ini merupakan rangkain kalimat yang disusun secara logis dan sistematis. Tujuannya agar peneliti bisa memahami objek yang diteliti dan memberikan jawaban sesuai rumusan masalah penilitinya. Hubungannya dengan tahap penyajian data, peneliti melakukan ringkasan yang relevan dengan bidang kajian yang diteliti. Hal ini dilakukan agar mempermudah peneliti dalam mengelompokkan dan menentukan simpulan.

Penyajian data dapat membantu kita untuk memahamai apa yang terjadi dan untuk melakukan sesuatu, baik itu untuk menganalisis lebih lanjut atau mengambil tindakan, berdasarkan apa yang dipahami. Tahap terakhir adalah tahap penarikan kesimpulan. Dalam tahap ini data-data yang sudah diperoleh akan ditarik kesimpulan yang menghasilkan sebuah teori dari penelitian tersebut.

\section{Hasil Dan Pembahasan}

Desa Meduri masuk dalam wilayah Kecamatan Margomulyo Kabupaten Bojonegoro dengan batas wilayah: Sebelah utara berbatasan dengan Desa Geneng, Sebelah selatan berbatasan dengan Desa Sumberejo, Sebelah barat berbatasan dengan Desa Sumberejo, dan Sebelah timur berbatasan dengan Desa Napis. Desa Meduri Kecamatan Margomulyo Kabupaten Bojonegoro memiliki luas wilayah $5970 \mathrm{Ha}$. Selain itu Desa Meduri Kecamatan Margomulyo Kabupaten Bojonegoro 
memeliki 10 Dusun yaitu Dusun Meduri, Dusun Kalijaran, Dusun Kunir, Dusun Pucang anom, Dusun Besali, Dusun kijang, Dusun Pleret, Dusun Kali gede, Dusun Kali dogol, Dusun Keren yang terdiri 16 RT dan 10 RW. Penduduk Desa Meduri Kecamatan Margomulyo Kabupaten Bojonegoro tahun 2018 penduduknya berjumlah 5,386 jiwa yang terdiri dari 2,647 penduduk laki-laki dan 2,739 penduduk wanita. Desa Meduri Kecamatan Margomulyo Kabupaten Bojonegoro memiliki jumlah Kepala Keluarga pada tahun 2017 berjumlah 1.705, dan kepadatan penduduk (c / luas desa) berjumlah 8,5 per $\mathrm{km}$.

Masyarakat Samin yang ada di Desa Meduri yang memiliki interaksi sosial yang masih terjaga baik dengan masyarakat lainya. Kegiatan kemasyarakatan di Desa masih masih terjaga dengan baik dan tidak ada perbedaan dengan masyarakat biasa, aliran Samin pertama kali di bawa oleh Sanin Surosendiko yang berasal dari Desa Ploso Kedhiren Randublatung Kabupaten Blora beliau memiliki pandangan pemikiran yang berbeda dengan masyarakat dengan umumnya.

Banyak masyarakat yang beranggapan aneh melihat masyarakat Samin karena masih memegang teguh nilainilai kebudayaan yang masih tradisional. Banyak anggapan bahwa masyarakat Samin adalah kumpulan orang-orang yang tak beragama, aneh dan terbelakang. Sebagian besar orang memandang dengan kaca mata buram atau dengan kaca mata negatif. Meraka memiliki pakean khas dalam berpakean menjadikan identitas dalam berpenampilan sehari-hari yang pembeda dengan masyarakat pada umumnya. Mereka menyakini ajaran Saminisme sebagai pandanagn hidup yang berguna dn bukti-bukti nyata yang di terima oleh ajaranya. Dalam ajaranya ini tidak boleh mencuri, jujur, kalau minjam barang orang lain harus di kembalikan, konsisten. pakean suwal panjang di bawah lutut, memakai ikat kepala, berkaos, masyarakat Samin memiliki watak ideal masyarakat Jawa.

Masyarakat Samin di Desa Meduri banyak yang berprofesi sebagai pengrajin dan pencari bonggol jati hal ini dikarenakan di Desa Meduri banyak pengepul dan pengolahan bonggol jati untuk menjadi kerajinan. Munculnya pekerjaan sebagai pencari bonggol jati di Desa Meduri dikarenakan adanaya permintaan dari pengepul yang meraka rasakan kekurangan bahan baku bonggol jati sebagai bahan baku kerajinan yang mereka butuhkan.

Oleh sebab itu, banyak permintaan dari pengepul yang membutuhkan bahan baku tersebut pengepul memberikan informasi kepada masyarakat sekitar Desa Meduri sebagai mata pencarian sambilan bagi masyarakat desa. Perintis paguyuban jati aji adalah pak subur sebagi pengrajin bonggol jati dan membuka usaha pertama kali yang ada di sana dan membuka 
lowongan pekerjaan bagi masyarakat yang memiliki pendidikan rendah dan yang tidak memiliki keterampilan yang memadai. Semakin- lama pekerjaan sebagi pengrajin bonggol jati di tekuni para masyarakat desa Meduri dan Geneng sebagai mata pencarian utama yang menghasilkan nilai ekonomis yang tinggi. Masyarakat Desa Meduri memilih pekerjaan sebagai pencari bonggol jati selain ada tawaran mereka juga pengrajin bonggol jati memiliki tingkat pendidikan yang rendah.

Akses perjalanan yang belum memadai ke tempat kerja dari rumah masyarakat sekitar $3 \mathrm{~km}$ perjalanan. Para kaum laki-laki juga menjadi pengrajin dan pencari bonggol jati selain itu mereka menjadi buruh tani jika udah selesai. Menunggu masa panen raya datang maka kaum laki-laki di Desa Meduri bekerja sebagi pengrajin dan pencari bongkahan bonggol jati untuk memenuhi kebutuhan kehidupan sehari-hari. Interaksi sosial yang di alami pengraji dan pencari bongkahan bonggol jati dengan masyarakat sekitar Desa Meduri dalam kondisi baik.

Pengrajin dan pencari bongkahan bonggol jati dalam melakukan hubungan interaksi juga seperti warga yang lainnya. Tidak ada perlakuan khusus mereka saling silahturahmi dan gotong royong antara dengan warga lainya dengan baik. Mereka lakukan berkomunikasi dan kontak sosial dengan masyarakat sekitar dengan bahasa yang sopan walaupun mereka tidak memiliki pendidikan tinggi. Mereka tetep menggunakan bahasa yang sopan ketika berinteraksi dengan masyarakat sekitar. mereka juga masih mempunyai sikap saling menghormati dan menghargai sesama warga ketika melakukan kontak sosial dengan orang lain secara baik. Antara pengrajin dan pencari bongkahan bonggol jati melakukan saling berinteraksi memiliki rasa simpati. Sikap simpati tersebut berkembang dalam satu relasi kerja sama antara dua orang atau kelompok saling mengerti satu dengan yang lainya.

Mereka saling membantu ketika ada kesulitan yang di alami salah satu pengrajin dan pencari bongkahan bonggol jati tidak mendapatkan hasil yang diharapkan. Atau saat mengalami kendala di jalan, mereka membantu bantuan temanya membawakan hasil yang mereka bawa untuk di setorkan ke pengepul biar dapat membawa uang untuk keluarganya. adanya perbedaan dalam masalah penerimaan upah yang di terima tetapi mereka tidak ingin bersaing dikarenakan mereka sadar dengan kemampuan yang meraka miliki.

Tumbuhnya kerjasama diantara pengrajin dan pencari bongkahan bonggol jati menjadikan pekerjaannya cepat selesai. Para pengrajin dan pencari bongkahan bonggol jati juga ikut serta dalam partisipasi dalam kegiatan sosial yang ada di Desa Meduri yaitu selain memberikan dana untuk pembuatan jalan, mereka juga ikut membantu pembangunan jalan di 
sekitar Desa Meduri meliputi Dusun Kali Dogol, Dusun Pucang Anom dan Dusun kunir. pengrajin dan pencari bongkahan bonggol jati juga ikut serta dalam kegiatan karang taruna, kerja bakti dan kegiatan arisan atau kumpulan setiap kepala keluarga yang diadaka setiap malam jum,at agar terciptanya rasa kekeluargaan yang erat dalam warga dan biar tidak ada pembeda diantara warga Desa. Pengrajin dan pencari bongkahan bonggol jati mereka adalah kelompok kerja yang ingin mencapai tujuan.

Yaitu, mendapat uang untuk memenuhi kebutuhan keluarga, setiap kelompok memiliki anggota kecil dan mempuyai tujuan yang sama. Rekrutmen pekerjaan pengrajin dan pencari bongkahan bonggol jati tidak ada syaratnya tertentu untuk menjalani sebagai pengrajian dan pencari bongkahan bonggol jati semua orang bisa masuk dan bekerja dari segala umur. karena pekerjaan ini tidak terikat dengan lembaga ataupun peraturan tertentu.

Lapisan sosial disetiap Desa pasti berbeda dengan yang lainya tergantung masyarakat yang berada di wilayah tersebut sehingga dapat memberikan lapisan sosial. Stratifikasi sosial di perdesaan erat hubungannya dengan setabilitas sosial ekonomi yang dimiliki seseorang yang berupa uang, Benda-benda yang bernilai jual ekonomis, tanah, kekuasaan, ilmu pengetahuan, kesoleha dan memiliki keturunan yang terhormat. Mereka yang memiliki harta yang berharga dengan jumlah yang banyak disebut kalangan atas dan sebalikya orang yang tidak memiliki harta benda disebut kalangan bawah. Lapisan atas yang ada di Desa Meduri diantaranya Kepala Desa, guru, pengepul bongkahan bonggol jati, TNI, Polisi, dan penggusaha besar, lapisa atas cenderung di segani atau di hormati dengan kalangan bawah. Lapisan menengah antara lain kariawan perusahaan, kariawan pemerintahan, perawat.

Lapisan sosial bawah selain pengrajin dan pencari bongkahan bonggol jati yaitu buruh tani, buruh migran, pembantu rumah tangga, bedanya pengrajian dan pencari bongkahan bonggol jati tidak memiliki upah yang tetap tergantung barang yang di perolehnya. Bisa juga disebut wong cilik tidak mempunyai kekuasaan yang berarti. Dapat dilihat dari ukuran tingkat kesejahteraan dari pengrajian dan pencari bonggkahan bonggol jati.

Mereka memiliki kekayaan yang tidak cukup banyak, kekeyaan tersebut dapat dilihat dengan cara berpakean, tempat tinggal dengan cara mereka berbagi dengan sesama. Dari upah yang mereka dapatkan hanya bisa memenuhi kebutuhan sehari-hari seperti makan dan biaya sekolah anaknya. Pengrajin dan pencari bongkahan bonggol jati tidak memiliki 
kekuasaan yang dapat memrpengaruhi kekuasaan. Mereka tidak mempuyai wewenang yang cukup dikarenakan mereka rasa tidak memiliki kekuasaan dan kekayaan yang banyak. Mereka memiliki kekuasaan penuh hanya sebagai kepala keluarga. Lapisan sosial dapat di golongkan dalam ukuran ilmu pengetahuan seperti tingkat pendidikan yanag tinggi maka mereka berada dalam lapisan atas. dan sebalikya kalau mereka memiliki tingkat pendidikan yang rendah mereka berada dalam lapisan bawah. Tinggkat pendidikan yang tinggi dan kekayaan yang mereka miliki berpengaruh dalam sistem kekuasaan dan kehormatan.

Ukuran kerhormatan dalam masyarakat menghormati orang-orang yang memiliki jasa kepada masyarakat, masyarakat juga menghormati pemuka agama ataupun orang yang di tuakan. Kondisi sosial pengrajian dan pencari bongkahan bonggol jati memiliki setratifikasi lapisan bawah dapat berubah dilapisan atas dengan usaha yang sungguhsungguh untuk memperbaiki sosial ekonomi mereka.

Pengrajin dan pencari bongkahan bonggol jati memiliki ekonomi yang rendah dapat diketahui dari kegiatan yang mereka lakukan ketika bekerja, upah dan aset yang mereka miliki. Pengrajin dan pencari bongkahan bonggol jati apa bila saat musim penghujan akan mempengaruhi hasil yang mereka peroleh karena sulitnya bahan baku yang mereka dapatkan dari hutan, warga atau TPK perhutani. Dan upah yang merek dapatkan tidak tetap dalam setiap harinya tinggal hasil yang mereka peroleh dan tidak memiliki pekerjaan yang tetap. Pengrajin dan pencari bongkahan bonggol jati memiliki sistem kerja dan pemberian upah dengan cara borongan. Borongan yaitu pekerjaan buruh cara pembayaranya atas dasar perhitungan hasil yang mereka peroleh. Mereka akan mendapat upah banyak apabila memperoleh hasil yang banyak.

Upah yang di terima pengrajin dan pencari bongkahan bonggol jati ada peningkatan yang dulunya mendapat upah Rp. 7000,- dan sekarang menjadi Rp. 15.000,-. Upah yang di dapatkan oleh pengrajin dan pencari bongkahan bonggol jati sebesar Rp. 15.000,- per hasil yang mereka per oleh, upah yang mereka dapatkan dalam penyetoran hasil bonggol jati yang masih bahan baku pengepul di hargai Rp 20.000,00 per bonggol jati yang berkualitas tinggi.

Penerimaan upah yang tidak menentu mereka akan mendapat upah yang banyak tinggal hasil yang mereka peroleh atua yang bisa di setoran ke pengepul. Upah yang dihasilkan tidak sesuai dengan UMR yang ada di Kabupaten Bojonegoro sebesar Rp 1.600,00. dikarenakan mereka tidak berada di bawah sebuah lembaga. Mereka akan mendapat upah apabila mereka menjual hasil 
pembuatan dan pencarian bongkahan bonggol jati ke pengepul. Upah yang bisa di hasilkan dalam perbulan jika ada pesanan yang mencapai Rp. 950.00,- untuk pencari bongkahan bonggol jati, pengrajin bongkahan jati Rp. 300,00-. Para pengrajin dan pencari bongkahan bonggol jati setiap bulan belum pasti mendapat upah sebesar Rp. 950.000,- dan Rp. 300.00,-. Karena menyesuaikan musim dan tergantunganya jumlah pesaan yang di peroleh. Upah yang diterima tidak mencukupi kebutuhan hidup keluarga.

Pengrajian dan pencari bongkahan bonggol jati tidak bisa membeli barang mewah. Tetapi cuma bisa memenuhi kebutuhan kehidupan sehari-hari, seperti makan dan biaya sekolah anak. Kebutuhan yang bisa dipenuhi sandang pangan dan papan. Karena bagi mereka tidak perlu dipikirkan sebab mereka tidak terlalu penting kebutuhan papan, yang utama pangan yang perlu dibutuhkan. Kebutuhan pangan yang tidak terlalu banyak hanya bisa memakan makanan yang dirasa sehat.

Untuk kesehatan mereka saja seperti nasi, lauk, sayur, papan tidak begitu di pedulikan karena perekonomian yang kurang. Mereka hanya bisa menyekolahkan anak-anakanya hanya sampai jenjang SMA. Pemenuhan kebutuhan perekonomian bisa dibilang rendah, namun apabila dapat memenuhi kebutuhan pokoknya dianggap mempunyai perekonomian atas. Pengrajin dan pencari bongkahan bonggol jati kumpulan tenaga kerja yang membuat kerajian dari bonggol jati dan mencari bongkahan bonggol jati dari hutan. Mereka memiliki umur 25 sampai 50 tahun. Kualitas kerja mereka sendiri dapat di tingkatkan melalui pendidikan dan pelatihan yang di selengarakan. Semakin pendidikan dan pelatihan yang di dapat oleh tenaga kerja mereka, maka kualitas yang dihasilkan semakin baik. Pengrajin dan pencari bongkahan bonggol jati dapat dimasukkan tenaga kerja fisik dan berfikir. Oleh sebab hanya mengandalkan fisik dan memiliki perekonomian yang rendah.

Uang yang mereka dapatkan bukan seperti masyarakat yang tenaga professional. Seperti pegawai negeri, guru dan dosen yang memiliki perekonomian baik. Masyarakat Desa Meduri memandang seseorang yang berada di lapisan atas melihat apa yang mereka miliki. Seperti kekayaan dan jabatan yang dimiliki orang tersebut.

Pengrajin dan pencari bongkahan bonggol jati hanya memiliki rumah dan kendaraan saja kepemilikan aset tersebut. Oleh sebab mereka menerima upah yang rendah. Di masyarakat terjadi kesenjangan ekonomi dan ketimpangan ekonomi dalam distribusi pendapatan antara masyarakat yang berpendapatan tinggi dan berpendapatan rendah. Pendapatan dijadikan sebagai penentu layak tidaknya kehidupan seseorang. Pendapatan bisa dijadikan penentu status yang ada di 
masyarakat, dengan melihat besar kecil upah yang diterima. Orang yang memiliki pendapatan perbulan lebih dari Rp. 1.600.000,-, mereka berada di perekonomian atas. Mereka yang memiliki pendapatan Rp. 1.000.000,- per bulan mereka berada di perekonomian menengah. Mereka memiliki upah yang di dapatkan dari hasil bekerja sebesar Rp. 700.000,-, tergolong perekonomian yang rendah. Dapat dikatakan pengrajin dan pencari bongkahan bonggol jati merupakan seseorang yang perekonomianya rendah. Kehidupan sosial ekonomi yang rendah kebutuhan yang harus dipenuhi semakin mahal. Banyak mereka yang mempertahankan pekerjaannya menjadi pengrajin dan pencari bongkahan bonggol jati kesulitan mencari lapangan pekerjaan.

Pada tahun sekarang tidak memiliki pendidikan yang tinggi dan mempunyai uang akan mendapat pekerjaan yang layak. Mereka selain menjadi pengrajin dan pencari bongkahan bonggol jati kehidupan mereka juga bekerja menjadi buruh tani pada musim tanam dan musim panen raya. Mereka juga menjadi buruh tani, agar mereka memenuhi kebutuhan sehari-hari.

Pengrajin dan pencari bongkahan bonggol jati, hanya mempunyai pekerjaan yang kurang bagus, sebab pendidikan hanya sampai SD maupun SMP. Upah yang tidak menentu tergantung barang dan hasil yang mereka dapatkan dan tidak sesuai UMR Kabupaten Bojonegoro. Semua itu sesuai dengan pekerjaan, pendidikan dan penghasilan yang di dapatkan mempunyai kehidupan sosial dan ekonomi yang rendah. Tidak bisa dikatakan untuk memenuhi kebutuhan dangan baik dan kesejahteraan hidupnya yang layak. Kegiatan belajar mengajar hendaknya tidak hanya terfokus di dalam ruang kelas yang kaku, terlebih dalam mata pelajaran IPSsejarah alangkah baiknya jika pembelajarannya dilakukan di luar kelas. Tujuannya supaya pembelajaran lebih menyenangkan dan tidak membosankan.

Mahasiswa dapat secara langsung mengamati berbagai kegiatan dan aktivitas yang dilakukan oleh masyarakat Samin di Bojonegoro. Jika melihat tradisi masyarakat Samin yang masih dilestarikan hingga kini. Ajaran Samin mengandung banyak nilai keluhuran. Maka sewajarnya keberadaan Samin ini dijaga dalam konteks pembangunan bangsa. Orang Samin mampu melestarikan budaya lokal sehingga nilai kearifan itu bisa merawat kebinekaan.

Ajaran Samin identik dengan kejujuran dan paseduluran atau persaudaraan. Konsep paseduluran tidak memandang ras, suku dan agama. Mereka merasa sebagai sesama makhluk sosial yang diciptakan Yang Maha Kuasa, yang bersosial sesama manusia, dan alam seisinya. Berdasarkan hal tersebut, kehidupan masyarakat Samin berpotensi sebagai sumber pembelajaran sejarah lokal. 
Jika dilihat dari kurikulum 2013 edisi revisi, maka KD yang sesuai adalah 3.6 Menganalisis perkembangan kehidupan masyarakat, pemerintahan, dan budaya pada masa kerajaan-kerajaan Hindu dan Buddha di Indonesia serta menunjukkan contoh bukti-bukti yang masih berlaku pada kehidupan masyarakat Indonesia masa kini. Meskipun masyarakat Samin berkembang sekitar abad ke- 18an, namun tradisi atau ajaran Samin diadopsi dari ajaran Hindu yang kemudian dikembangkan dalam ajaran kejawen dan tertuang pada serat Jamus Kalimosodho.

\section{Kesimpulan}

Munculnya pekerjaan pengrajin dan pencari bongkaahan bonggol jati adanya perintis pengrajin paguyuban jati aji. Banyak masyarakat Desa memiliki pendidikan yang rendah dan tidak memiliki keahlian yang mumpuni. Sehingga pak subur memberi informasi kepada masyarakat untuk membantu perusahaan yang dulunya kekurangan bahan baku yaitu, bonggol jati untuk mencari bongkahan bonggol jati. Mereka menjadi pencari bongkahan bonggol jati, oleh sebab memiliki pendidikan rendah dan tidak memiliki keahlian untuk pekerjaan yang lain guna pemenuhan sehari-hari.

$$
\text { Interaksi sosial penting }
$$

dikarenakan setiap manusia membutuhkan pertolongan dari orang lain dan harus selalu melakukan komunikasi. Interaksi sosial masyarakat di Desa Meduri masih terjaga seperti gotong royong dan kekeluargaan hingga sekarang. Kondisi sosial kekayaan, kekuasaan dan pendidikannya mempunyai kondisi sosial berada di lapisan bawah. Kondisi sosial yang di alami tidak terlalu baik. Oleh sebab upah yang diterima tidak terlalu besar. Masyarakat Meduri masih memprihatinkan sebab merupakan salah satu Desa tertinggal. Dikarenakan akses jalan Desa yang belum baik dan tempat tinggal di hutan masih semakin terisolasi. Masih banyak masyarakat yang belum mendapatkan fasilitas alat komuniksi dan listrik. Masyarakatnya masih kekurangan ekonomi sehingga banyak anak-anaknya belum menempuh pendidikan. Anggapannya karena untuk makan saja susah, apalagi menyekolahkan anak.

\section{Daftar Pustaka}

Juariyah, S. (2010). Analisis Kondisi Sosial Ekonomi dan Tingkat Pendidikan Masyarakat Desa Srigading, Kecamatan Labuhan Maringgai, Kabupaten Lampung Timur. Jurnal Ekonomi dan Pendidikan, 7(1).

Miles, M. B., \& Huberman, M. A. (1994). Qualitative Data Analysis. California: SAGE Publications, Inc.

Munadi, M. (2014). Budaya Politik Masyarakat Samin (Sedulursikep) (Studi Kasus di Dukuh Mbombong Desa Baturejo Kecamatan Sukolilo Kabupaten Pati Provinsi Jawa Tengah). Politika: Jurnal Ilmu Politik, 4(1), 69-79.

Abraham, N., \& Soebijantoro., \& Muhammad, H., \& Hartono, Y. (2013). Ilmu Sosial \& Budaya Dasar. Madiun: Institut Press IKIP PGRI Madiun. 
Septikawati, I., \& Habsari, N. T. (2014). Perubahan Sosial Kaum Perempuan Samin Di Desa Klopoduwur Kecamatan Banjarejo Kabupaten Blora Tahun 1995-2012. AGASTYA: JURNAL SEJARAH DAN PEMBELAJARANNYA， 4(02), 113134

Sukmadinata, S. N. (2011). Metode Penelitian Pendidikan. Bandung: PT Remaja Rosdakarya.

Dadang, S. (2013). Pengantar Ilmu Sosial Sebuah Kajian Pendekatan Struktural. Jakarta : PT Bumi Aksara

Soelaeman. (2011). Ilmu Sosial Dasar Teori san Konsep Ilmu Sosial. Bandung: PT Refika Aditama

Zunaidi, M. (2013). Kehidupan Sosial Ekonomi Pedagang Di Pasar Tradisional Pasca Relokasi Dan Pembangunan Pasar Modern. Jurnal Sosiologi Islam, 3(1). 